\title{
On the Variability of Surface Tension with Mean Wind Speed
}

\author{
Heinrich Hühnerfuss and Wolfgang Waiter \\ Institut für Organische Chemie und Biochemie, Universität Hamburg, Federal Republic of Germany
}

GOTTFRIED KRUSPE

Max-Planck-Institut für Meteorologie, Hamburg, Federal Republic of Germany

(Manuscript received 12 October 1976, in revised form 21 March 1977)

\begin{abstract}
In situ measurements of surface tension obtained by R. V. Gauss under coastal (North Sea off the Island of Sylt) and by R. V. Meteor under open sea conditions (GATE area) are compared with time variations of the surface mean wind speed. The results indicate that the surface tension of the sea sur-

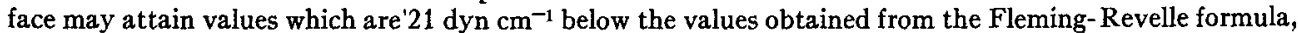
if the mean wind speed decreases steadily to less than $5 \mathrm{~m} \mathrm{~s}^{-1}$ and the biological productivity within the upper layers of the water is significant.
\end{abstract}

\section{Introduction}

Occasionally, artificial and natural monomolecular surface films ("slicks") occur at the air-sea interface, in particular in coastal areas. These slicks modify the air-sea interaction processes in different ways, for instance by capillary wave damping (Garrett, 1967), retardation of evaporation (LaMer, 1962), gas exchange (Hawke and Alexander, 1962; Petermann, 1976), heat transfer (Shulman and Teorell, 1938; Jarvis, 1962; Jarvis et al., 1962; Mann et al., 1971), light transmission and reflection (Cox and Munk, 1955; Garrett, 1969), and spray and whitecap reduction (Miller, 1972). Furthermore, Blanchard (1964) postulated that organic films on the sea surface may influence the oceanic production of condensation nuclei necessary for cloud formation. The decrease of evaporation caused by slicks could be applied to modification of tropical mesoscale storm activity (Mallinger and Mickelson, 1973). When interpreting meteorological and oceanographic data from the air-sea interface, the occurrence of slicks should be taken into consideration. For instance, remote sensing methods using active radar backscatter from the sea surface are strongly affected by the state of the capillary wave spectrum. If the presence of slicks is neglected, the interpretation of the results may be erroneous.

Present knowledge about formation of such slicks is fragmentary. With regard to the film-forming material of natural slicks, Barger et al. (1974), Brockmann et al. (1976), Jarvis et al. (1967) and Williams (1967) have analyzed surface films and found that the film forming material is secreted by planctonic material. Consequently, a high biological productivity in the water column is necessary for the formation of natural films. The present study is devoted to the mean wind field within the marine surface layer as the most important meteorological factor for the formation and destruction of natural surface films during high biological productivity. This is to be demonstrated from simultaneous measurements of surface tension and mean wind speed.

\section{Data and methods}

The surface tension data reported here collected during daytime under conditions of light and moderate winds 1) during the surface film project $\mathrm{KOFF}$ (Kombiniertes Oberflächen Film Projekt) in the coastal area of the North Sea (off the island of Sylt) from 3 to 22 August 1974, and 2) during GATE from 16 June to 23 September 1974, in the tropical Atlantic at the position of R.V. Meteor $\left(\phi=7.8-13.3^{\circ} \mathrm{N}, \lambda\right.$ $=15-23.5^{\circ} \mathrm{W}$ ).

Surface films can be identified by the fact that they significantly reduce the surface tension. The spreading oil method (Adam, 1937) yields reliable in situ values of surface tension of a dynamic water surface under conditions of light to moderate winds. The set of test oils used in the experiments was prepared by mixing known quantities of 1-dodecanol with nonspreading paraffin oil. After calibration of a hydrophil balance (Langmuir trough) by the piston monolayer technique (Adam, 1937; Zisman, 1941), the accuracy of the resulting surface tension measurements is approximately $\pm 0.5 \mathrm{dyn} \mathrm{cm}^{-1}$. From the actual surface tension measurements the surface tension lowering effect of slicks can be determined by 


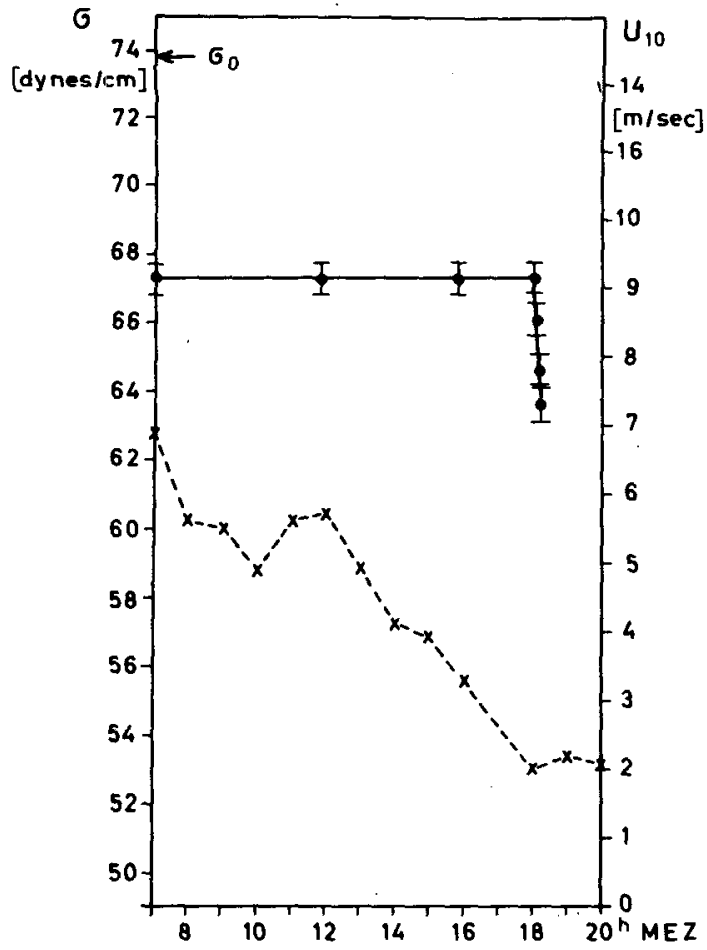

FrG, 1. Daytime variation of surface tension (solid line) and $60 \mathrm{~min}$ average mean wind at $10 \mathrm{~m}$ (dashed line) for KOFF experiment off the island of Sylt, 3 August 1974. The mean surface tension of pure sea water is $\sigma_{0}=73.8 \mathrm{dyn} \mathrm{cm}^{-1}$.

subtracting the empirical Fleming-Revelle surface tension $\sigma_{0}$ of pure sea water, $\sigma_{0}=75.64-0.144 t_{w}+0.0399 \mathrm{Cl}$ (Fleming and Revelle, 1939), where $t_{w}$ is the tem-

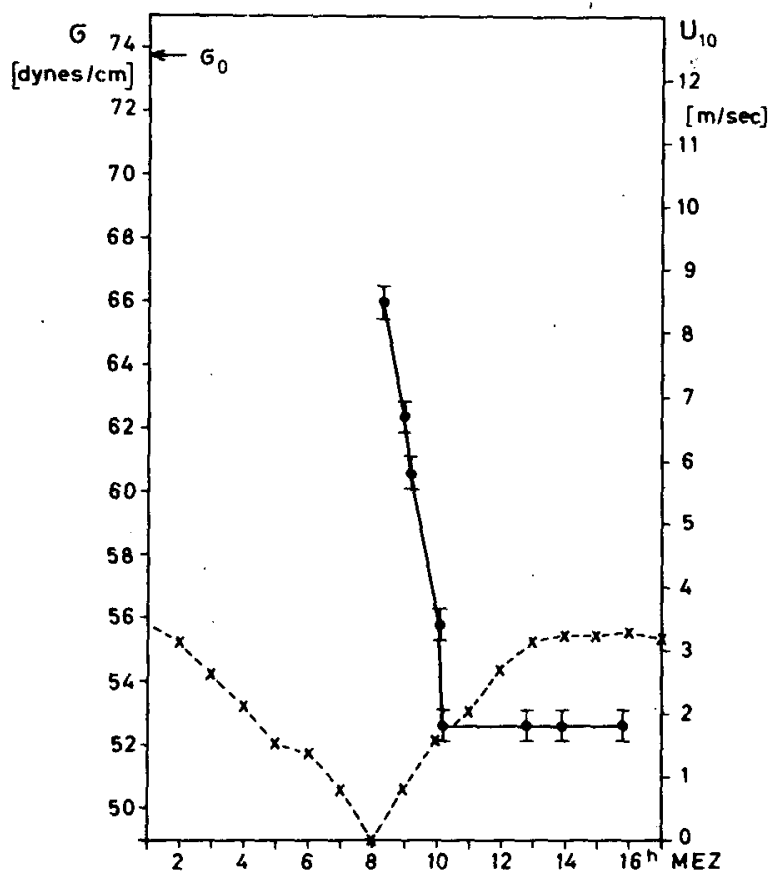

Fig. 2. As in Fig. 1 except for 21 August 1974.
TABLE 1. Surface tension and wind speed measurements off the island of Sylt on 13 August 1974. The theoretical mean surface tension of pure sea water is $\sigma_{0}=73.8 \mathrm{dyn} \mathrm{cm}^{-1}$.

\begin{tabular}{|c|c|c|}
\hline $\begin{array}{l}\text { Time } \\
\text { (MEZ) }\end{array}$ & $\begin{array}{c}\text { Wind speed } \\
U_{10} \\
\left(\mathrm{~m} \mathrm{~s}^{-1}\right)\end{array}$ & $\begin{array}{c}\text { Surface tension } \\
\sigma \\
\left(\text { dyn } \mathrm{cm}^{-1}\right)\end{array}$ \\
\hline 0700 & 6.9 & 67.3 \\
\hline 0800 & 5.6 & - \\
\hline 0900 & 5.5 & - \\
\hline 1000 & 4.9 & - \\
\hline 1100 & 5.6 & - \\
\hline 1200 & 5.7 & - \\
\hline 1300 & 4.9 & 67.3 \\
\hline 1400 & 4.1 & 一 \\
\hline 1500 & 3.9 & - \\
\hline 1600 & 3.3 & 67.3 \\
\hline 1700 & 2.6 & - \\
\hline 1800 & 2.0 & 67.3 \\
\hline 1802 & - & 67.0 \\
\hline 1804 & - & 66.0 \\
\hline 1806 & - & 64.6 \\
\hline 1808 & - & 64.3 \\
\hline 1810 & - & 63.6 \\
\hline 1900 & 2.2 & - \\
\hline 2000 & 2.1 & - \\
\hline
\end{tabular}

perature $\left({ }^{\circ} \mathrm{C}\right)$ of the upper water layer and $\mathrm{Cl}$ the chlorinity $(\%)$. In the actual project, the test oil droplets were applied to the sea surface downwind from a rubber raft at a considerable distance from the ship.

The wind data from the GATE area are based on cup anemometer profile observations measured on the meteorological buoy of the Meteorological Institute

Table 2. As in Table 1 except for 21 August 1974.

\begin{tabular}{|c|c|c|}
\hline $\begin{array}{c}\text { Time } \\
\text { (MEZ) }^{*}\end{array}$ & $\begin{array}{c}\text { Wind speed } \\
U_{10} \\
\left(\mathrm{~m} \mathrm{~s}^{-1}\right)\end{array}$ & $\begin{array}{c}\text { Surface tension } \\
\sigma \\
\left(\text { dyn } \mathrm{cm}^{-1}\right)\end{array}$ \\
\hline 0100 & 3.4 & - \\
\hline 0200 & 3.1 & - \\
\hline 0300 & 2.6 & - \\
\hline 0400 & 2.1 & - \\
\hline 0500 & 1.5 & - \\
\hline 0600 & 1.4 & - \\
\hline 0700 & 0.8 & - \\
\hline 0800 & 0.0 & - \\
\hline 0820 & - & 66.0 \\
\hline 0900 & 0.8 & - \\
\hline 0905 & - & 62.4 \\
\hline 0910 & - & 60.6 \\
\hline 1000 & 1.5 & - \\
\hline 1005 & - & 55.8 \\
\hline 1010 & - & 52.6 \\
\hline 1100 & 2.0 & - \\
\hline 1200 & 2.7 & - \\
\hline 1300 & 3.1 & 52.6 \\
\hline 1400 & 3.2 & 52.6 \\
\hline 1500 & 3.2 & - \\
\hline 1600 & 3.3 & 52.6 \\
\hline 1700 & 3.1 & - \\
\hline
\end{tabular}

* Mittel Europäische Zeit. 


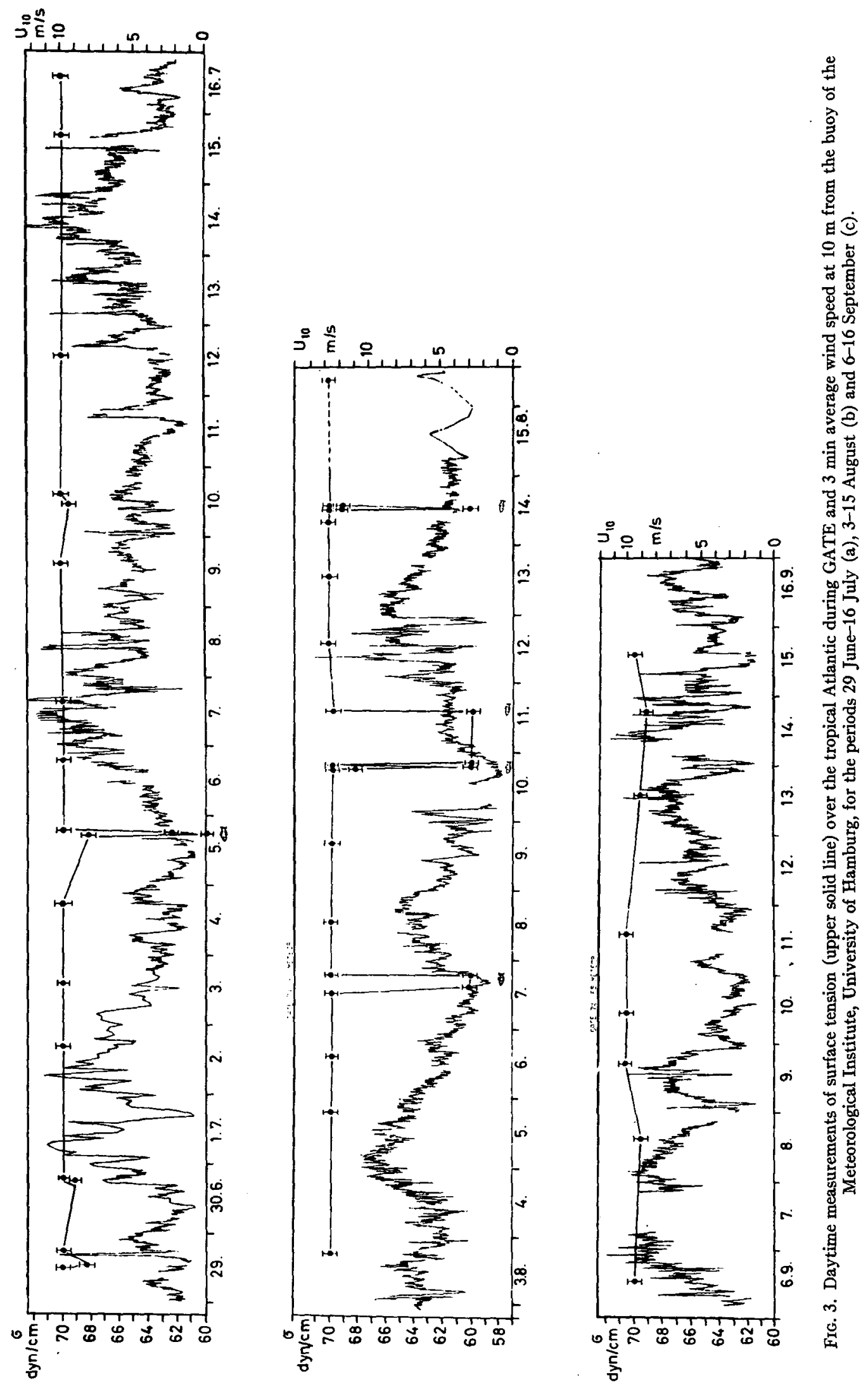


TABLE 3. Surface tension and wind speed measurements in the GATE area, 29 June-16 July 1974.

\begin{tabular}{|c|c|c|c|c|}
\hline \multirow[b]{2}{*}{ Date } & \multirow[b]{2}{*}{$\begin{array}{c}\text { Time } \\
\text { (GMT) }\end{array}$} & \multirow{2}{*}{$\begin{array}{c}\text { Wind } \\
\text { speed } \\
U_{10} \\
\left(\mathrm{~m} \mathrm{~s}^{-1}\right)\end{array}$} & \multicolumn{2}{|c|}{ Surface tension $\sigma_{0}$} \\
\hline & & & $\begin{array}{l}\text { Theoretical } \\
\text { (dyn } \mathrm{cm}^{-1} \text { ) }\end{array}$ & $\begin{array}{c}\text { Observed } \\
\left(\text { dyn } \mathrm{cm}^{-1}\right)\end{array}$ \\
\hline \multirow[t]{3}{*}{29 June } & 1240 & 1.6 & 72.5 & 70.1 \\
\hline & 1350 & 1.6 & 72.5 & 68.4 \\
\hline & 1830 & 4.5 & 72.5 & 70.1 \\
\hline \multirow[t]{2}{*}{30 June } & 1850 & 7.0 & 72.5 & 69.2 \\
\hline & 1900 & 5.5 & 72.5 & 70.0 \\
\hline 2 July & 1630 & 6.1 & 72.5 & 70.0 \\
\hline 3 July & 1410 & 4.2 & 72.5 & 70.0 \\
\hline 4 July & 1900 & 4.5 & 72.5 & 70.0 \\
\hline \multirow[t]{4}{*}{5 July } & 1845 & 3.0 & 72.5 & 68.3 \\
\hline & 1853 & 1.3 & 72.5 & 60.3 \\
\hline & 1900 & 2.4 & 72.5 & 62.7 \\
\hline & 1920 & 3.5 & 72.5 & 70.0 \\
\hline 6 July & 2000 & 8.0 & 72.5 & 70.0 \\
\hline 7 July & 1700 & 10.0 & 72.5 & 70.0 \\
\hline 9 July & 1600 & 5.0 & 72.5 & 70.1 \\
\hline \multirow[t]{2}{*}{10 July } & 1200 & 3.8 & 72.6 & 69.7 \\
\hline & 1600 & 4.9 & 72.5 & 70.1 \\
\hline 12 July & 1400 & 3.0 & 72.6 & 70.1 \\
\hline 15 July & 1800 & 6.3 & 72.6 & 70.1 \\
\hline 16 July & 1400 & 3.5 & 72.6 & 70.1 \\
\hline
\end{tabular}

of University of Hamburg upwind of the ship. The wind record in Fig. 3 represents $3 \mathrm{~min}$ average values at a reference height of $10 \mathrm{~m}$. During the KOFF experiment, the wind data were collected at the top of the ship's mast at a height of nearly $10 \mathrm{~m}$. The wind data in Figs. 1 and 2 represent $60 \mathrm{~min}$ average values.

\section{Discussion of results}

The measurements are shown as time series of the quantities $\sigma$ and $u_{10}$ in Figs. 1-3, as well as in Tables 1-5. From the KOFF data it was possible to determine daytime variation of the surface tension in two special cases, whereas the GATE series may be considered as sporadic samples over a longer period. Here the biological productivity was based on the observed presence of small fish.

As can be seen in Fig. 2, a natural slick was observed during the entire daylight measurement period. In the morning at about 0900 only a small fraction of the surface was covered with slicks. However, by 1400 nearly the whole area off the island of Sylt was covered with slick material, leaving only small holes a few square meters in area of uncontaminated water. The slick material was analyzed by Brockmann $e t$ al. (1976). The formation of slicks leads to a decrease of surface tension of about $21.2 \mathrm{dyn}^{-1}$ compared to the Fleming-Revelle value of $\sigma_{0}=73.8 \mathrm{dyn} \mathrm{cm}^{-1}$. In holes which could be recognized from a helicopter by the rough appearance of the water surface, the decrease of surface tension was only $6.5-6.8 \mathrm{dyn}^{-1}$. From Figs. 1 and 2 it would appear that slicks are
TABLE 4. As in Table 3 except for 3-18 August 1974.

\begin{tabular}{|c|c|c|c|c|}
\hline \multirow[b]{2}{*}{$\begin{array}{c}\text { Date } \\
\text { (August) }\end{array}$} & \multirow[b]{2}{*}{$\begin{array}{l}\text { Time } \\
\text { (GMT) }\end{array}$} & \multirow{2}{*}{$\begin{array}{c}\text { Wind } \\
\text { speed } \\
U_{\mathrm{t} 0} \\
\left(\mathrm{~m} \mathrm{~s}^{-1}\right)\end{array}$} & \multicolumn{2}{|c|}{ Surface tension $\sigma_{0}$} \\
\hline & & & $\begin{array}{l}\text { Theoretical } \\
\left(\text { dyn } \mathrm{cm}^{-1}\right)\end{array}$ & $\begin{array}{c}\text { Observed } \\
\left(\text { dyn } \mathrm{cm}^{-1}\right)\end{array}$ \\
\hline 3 & 1700 & 6.7 & 72.6 & 70.1 \\
\hline 5 & 1845 & 7.0 & 72.6 & 70.1 \\
\hline 6 & 1400 & 4.7 & 72.6 & 70.1 \\
\hline \multirow[t]{4}{*}{7} & 1335 & 2.7 & 72.5 & 70.0 \\
\hline & 1340 & 2.5 & 72.5 & 60.3 \\
\hline & 1930 & 2.7 & 72.5 & 60.3 \\
\hline & 1935 & 3.8 & 72.5 & 70.0 \\
\hline 8 & 1350 & 6.7 & 72.5 & 70.0 \\
\hline 9 & 1700 & 3.9 & 72.5 & 70.0 \\
\hline \multirow[t]{5}{*}{10} & 1855 & 1.1 & 72.4 & 69.8 \\
\hline & 1904 & 1.3 & 72.4 & 68.2 \\
\hline & 1906 & 1.3 & 72.4 & 60.2 \\
\hline & 1907 & 1.5 & 72.4 & $69.8^{*}$ \\
\hline & 1909 & 1.8 & 72.4 & 60.2 \\
\hline \multirow[t]{2}{*}{11} & 1430 & 4.0 & 72.5 & 60.2 \\
\hline & 1435 & 4.8 & 72.5 & 70.0 \\
\hline 12 & 1500 & 7.5 & 72.5 & 70.1 \\
\hline 13 & 1940 & 7.1 & 72.5 & 70.1 \\
\hline \multirow[t]{6}{*}{14} & 0930 & 4.8 & 72.5 & 70.1 \\
\hline & 1902 & 4.1 & 72.5 & 70.0 \\
\hline & 1905 & 3.7 & 72.5 & 69.1 \\
\hline & 1910 & 4.6 & 72.5 & 60.3 \\
\hline & 1917 & 4.5 & 72.5 & 69.1 \\
\hline & 1925 & 4.7 & 72.5 & 70.0 \\
\hline 16 & 1100 & 5.0 & 72.5 & 70.0 \\
\hline 18 & 1203 & 5.2 & 72.5 & 70.0 \\
\hline
\end{tabular}

* Hole in the slick.

coupled with a steady decrease of wind speed to a low level some hours before.

In the case given in Fig. 2, the well-established slick could not be affected by the small increase in wind speed to $3.3 \mathrm{~m} \mathrm{~s}^{-1}$. It should also be emphasized that the wind speed below which slicks can be formed and the value of maximum surface tension lowering may depend on the slick-forming material, which itself depends on its biogen origin. The wind speed below which slicks can be formed and the wind speed for destruction of a slick are not necessarily identical because the roughness of the sea surface with and

Table 5. As in Table 3 except for 6-15 September 1974.

\begin{tabular}{ccccc}
$\begin{array}{c}\text { Wind } \\
\text { Date } \\
\text { (September) }\end{array}$ & $\begin{array}{c}\text { Time } \\
\text { speed } \\
(\mathrm{GMT})\end{array}$ & $\begin{array}{c}U_{10} \\
\left(\mathrm{~m} \mathrm{~s}^{-1}\right)\end{array}$ & $\begin{array}{c}\text { Surface tension } \sigma_{0} \\
\text { Theoretical } \\
\left(\text { dyn } \mathrm{cm}^{-1}\right)\end{array}$ & $\begin{array}{c}\text { Observed } \\
\left(\text { dyn } \mathrm{cm}^{-1}\right)\end{array}$ \\
\hline 6 & 1300 & 6.0 & 72.5 & 70.0 \\
8 & 1550 & 7.6 & 72.5 & 69.5 \\
9 & 1848 & 6.9 & 72.5 & 70.6 \\
10 & 1117 & 2.7 & 72.5 & 70.5 \\
11 & 1500 & 3.0 & 72.4 & 70.4 \\
13 & 1445 & 7.0 & 72.4 & 69.5 \\
14 & 1830 & 5.8 & 72.5 & 69.2 \\
15 & 1431 & 4.0 & 72.5 & 70.0 \\
\hline
\end{tabular}


without slicks is quite different under the same wind conditions. While significant surface tension lowering in coastal areas has already been reported, no data are available from the open ocean. For this reason the surface tension measurements over the longer GATE period are of particular interest (see Fig. 3 and Tables 3-5). The data show a trend similar to those observed in coastal areas. If the wind speed decreases steadily formation of slicks occurs some hours later provided that biological productivity exists.

Since the relative intensities of ocean and atmosphere surface layer turbulence are related to the surface stress, it would appear that natural slicks can only form if there is a sufficient reduction in the wind-induced turbulent mixing of the upper water layers. This has been argued intuitively by other authors (Ewing, 1950; Garrett, 1969, 1971; Jarvis, 1965, 1967; Lumby and Folkard, 1956) and seems to be confirmed by the data presented here.

\section{Conclusion}

In summary, the data indicate that slick formation is possible when the wind changes slowly from higher to lower levels (say, 3-5 $\mathrm{m} \mathrm{s}^{-1}$ ). If the wind speed remains low, natural slicks can persist over hours or even days. Off the island of Sylt, natural slicks persisting over $32 \mathrm{~h}$ have been observed, whereas in the GATE area the wind increased several hours so that the slick-forming material was either submerged by the induced turbulence of the water or removed from the water surface by a bubbling mechanism as described by Blanchard (1964).

More measurements are needed in order to clarify the relations between chemical constitution, surface tension lowering and turbulent state of the upper water layers. The data stress the necessity that meteorological and oceanographic measurements at the air-sea interface should account for the presence of slicks.

Acknowledgments. This research has been sponsored by the Deutsche Forschungsgemeinschaft (German Science Foundation), through the Sonderforschungsbereich 94-Meeresforschung. The Deutsche Texaco AG generously provided the nonspreading paraffin oil.

\section{REFERENCES}

Adam, N. K., 1937 : A rapid method for determining the lowering of tension of exposed water surfaces, with some observations on the surface tension of the sea and of inland waters. Proc. Roy. Soc. London, B122, 134-139.

Barger, W. R., W. H. Daniel and W. D. Garrett, 1974: Surface chemical properties of banded sea slicks. Deep Sea Res., 21, 83-89.

Blanchard, D. C., 1964: Sea-to-air transport of surface active material. Science, 146, 396-397.

Brockmann, U., G. Kattner, G. Hentzschel, K. Wandschneider, H. D. Junge and H. Hühnerfuss, 1976: Natürliche Oberflächenfilme im Seegebiet vor Sylt. Mar. Biol., 36, 135-146.

Cox, C., and W. Munk, 1955 : Some problems in optical oceanography. J. Mar. Res., 14, 63-78.

Ewing, G., 1950: Slicks, surface films and internal waves. $J$. Mar. Res., 9, 161-187.

Fleming, R. H., and R. R. Revelle, 1939: Recent marine sediments. Amer. Assoc. Pelrol. Geol. Bull., 48, 48-141.

Garrett, W. D., 1967: Damping of capillary waves of the air-sea interface by oceanic surface-active materials. J. Mar. Res., 25, 279-291.

-1969 : Surface-chemical modification of the air-sea interface. Ann. Meleor., N.F., 4, 25-29.

1971: The changing chemistry of the oceans. Proc. 20th Nobel Symposium, D. Dyrssen and D. Jagner, Eds., Göte borg, Sweden.

Hawke, J. G., and A. Alexander, 1962: The influence of surfaceactive compounds upon the diffusion of gases across the air-water interface. Retardation of Evaporation by Monolayers, V. K. LaMer, Ed., Academic Press, 67-73.

Jarvis, N. L., 1962: The effect of monomolecular films on surface temperature and convective motion of the water/air interface. J. Colloid Sci., 17, 512-522.

- 1965 : Adsorption of surface-active material of the surface of sea-water samples from the Bay of Panama. Naval Res. Lab. Rep. 6325, 20 pp.

- 1967 : Adsorption of surface-active material at the sea-air interface. Limnol. Oceanogr., 12, 213-221.

- C. O. Timmons and W. A. Zisman, 1962: The effect of monomolecular films on the surface temperature of water. Retardation of Evaporation by Monolayers, V. K. LaMer, Ed., Academic Press, 41-58.

- W. D. Garrett, M. A. Scheimann and C. O. Timmons, 1967: Surface chemical characterization of surface-active material in sea water. Limnol. Oceanogr., 12, 88-96.

LaMer, V. K., Ed., 1962 : Retardation of Evaporation by Monolayers. Academic Press, 277 pp.

Lumby, J. R., and A. R. Folkard, 1956: Variation in the surface tension of the sea water in situ. Bull. Inst. Oceanogr., No. 1080, Monaco.

Mallinger, W. D., and T. P. Mickelson, 1973: Experiments with monomolecular films on the surface of the open sea. J. Phys. Oceanogr., 3, 328-336.

Mann, H., E. Scherf and M. Wassermann, 1971: Einfluß der Wasserbedeckung mit Fettalkoholen auf die Wassertemperatur in Karpfenteichen. Arch. Fischereiwiss., 22, 68-78.

Miller, R. L., 1972: The role of surface tension in breaking waves. Proc. 13th Coastal Engineering Conf., Vancouver, Amer. Soc. Civ. Engrs. 433-449.

Petermann, J., 1976: Der Einfluß der Oberflächenspannung wässeriger Systeme auf die Kinetik des Gasaustausches. Ph.D. thesis, Universität Hamburg.

Shulman, J. H., and T. Teorell, 1938: On the boundary layer at membrane and monolayer interfaces. Trans. Faraday Soc., 34, 1337-1342.

Williams, P. M., 1967: Sea surface chemistry: Organic carbon and organic and inorganic nitrogen and phosphorus in surface films and subsurface waters. Deep Sea Res., 14, 791-800.

Zisman, W. A., 1941: The spreading of oils on water, Part III. Spreading pressures and the Gibbs adsorption relation. J. Chem. Phys., 9, 789-793. 